\title{
EFFECT OF FORTIFICATION OF EGGS WITH FOLIC ACID DURING INCUBATION AND POST HATCH ASCORBIC ACID SUPPLEMENTATION ON PRODUCTIVE PERFORMANCE, BLOOD CONSTITUENTS AND IMMUNE STATUS OF BROILER CHICKS
}

\author{
Eman A. EI Said \\ Poultry Production Department, Faculty of Agriculture, Damietta University, Damitta, Egypt.
}

(Received 23/5/2017, Accepted 11/7/2017)

\section{SUMMARY}

$\mathrm{T}$ he present study aimed to evaluate the effect of in ovo injection with Folic acid and adding ascorbic acid (VC) into the drinking water on growth performance, carcass yield, some blood biochemical changes and immune response of broiler chicks. A total of 150 eggs were randomly divided into three groups. The $1^{\text {st }}$ one has no treatment (control), while the $2^{\text {nd }}$ was in ovo injected with $0.1 \mathrm{ml}$ distilled water/egg (Sh - group). The third one was given injected by folic acid 10\% ( $0.1 \mathrm{ml} / \mathrm{egg})$. Feeding and flock management were done in accordance with commercial practices. The results indicated that chicks hatched from eggs treated with folic acid or folic acid and then given VC in the drinking water had higher body weight, carcass (\%), breast muscle yield and lymphoid organs weight than other treatments. The visceral organs of the birds likewise increased. Plasma concentration of total lipid, cholesterol, triglycerides and LDL were significantly decreased by both folic acid injection and VC addition to drinking water. Addition of VC was effective on increasing intestinal total count of bacteria while, decreasing intestinal count of Escherichia coli. It could be successfully used as alternative to antibiotic growth promoters as a tool of controlling intestinal pathogenic bacteria.

Keywords: Broiler chicks, Embryo, Folic acid, Vitamin C, Muscle, Blood Parameters, pathogenic bacteria.

\section{INTRODUCTION}

Nowadays, there is a linear enhancement in the growth performance and meat yield of commercial poultry with the best input efficiency all over the year. Development of the embryo, promotes early gut development and improve immune status by introducing nutrients to the incubating embryo through in ovo injection (Havenstein et al., 2003; Tako et al., 2005 and Foye et al., 2007). In ovo injection is excessively used for plenty of purposes, such as injecting eggs with immunological materials (Jochemsen and Jeurissen, 2002), raising the post-hatching body weights of birds (Ohta et al., 1999), enhanced immune response; enhanced early growth by refine intestinal function and development (Tako et al., 2004); increased skeletal growth (Hargis et al., 1989), breast muscle yield (Hajihosaini and Mottaghitalab, 2004), and body market weight (Selim et al., 2012). Folic acid is major for cell division and body functions, therefore it is essential for embryo development. A possible approach to counteracting the negative effects of heat stress among chickens was the supplementation of birds with Vitamin C; which plays a major role in the biosynthesis of corticosterone (Bain, 1996). Several researchers have reported beneficial effects of Vitamin C supplements (given either in diets and or in drinking water) in enhanced performance of broiler chickens with experimentally induced hypothyroidism (Takahashi et al., 1991), and improved disease resistance of the birds (Amakye-Anim et al., 2000). Skinner et al. (1991) reported that vitamins supplementation via the drinking water can be an effective alternative method to provide the birds with extra nutrients to maintain good performance especially during unusual conditions

Therefore, the present study was conducted to elucidate the influence of in ovo injection of folic acid (FA) during incubation and post hatching vitamin $\mathrm{C}$ addition in drinking water on productive performance, some blood parameters and immune responses of broiler chicks. 


\section{MATERIALS AND METHODS}

\section{Experimental Procedures:}

A total number of 150 eggs with an average weight of $67 \mathrm{~g}$ were obtained from a commercial broiler breeder flock (Ross). Before incubation, eggs were randomly divided into three groups of 50 eggs each . The first group, was intact non-injected eggs, considered as control (C), while the second and third groups were injected into air cell with $0.1 \mathrm{ml}$ distilled water/egg as solvent and $0.1 \mathrm{ml} \mathrm{FA}(10 \%)$ respectively . All eggs were normally incubated in a forced draught Laboratory Incubator at the recommended incubation temperature $\left(37.6-37.7^{\circ} \mathrm{C}\right)$ and relative humidity $(\mathrm{RH})$ between 55 to $60 \%$ in an automatic incubator. Egg injection procedure was carried out at day 7of embryonic development. Thus, the large end of each egg (location of air cell) was disinfected by ethyl alcohol. The point site of injection was punctured by hard and thin stylus and the tested material was injected into the air cell of each egg by using graded insulin syringe $(1 \mathrm{ml})$ and the punctured site was sealed with non-toxic glue sticks. The injected dose was $0.1 \mathrm{ml} / \mathrm{egg}$. At the $18^{\text {th }}$ day of incubation, all eggs were transferred to the Hatcher and kept till hatching at $37.5^{\circ} \mathrm{C}$ and $70 \% \mathrm{RH}$. The hatched chicks from each group were sub-divided into two vitamin $\mathrm{C}(\mathrm{VC})$ - treatment groups. VC was supplied in drinking water of newly hatched chicks at 0 (control) or $40 \mathrm{mg} / \mathrm{L}$ of drinking water. Since 6 expermintal treatments were existed ( 2 Vit. C levels X 3 in ovo folic acid treatments). All chicks were fed ad-libitum on commercial starter (1 to $16 \mathrm{~d}$ ), grower $(16-30 \mathrm{~d})$ and finisher $(30-35 \mathrm{~d})$ diets. The birds were given the same management and vaccination program as those done in commercial farms.

\section{Slaughter test:}

At the end of the experimental period ( 5 weeks of age), three chicks from each group were randomly taken and slaughtered by severing the carotid arteries and jugular veins. After complete bleeding, chicks were scalded in hot water bath then eviscerated and weighed to determine the hot carcass weight as well as giblets (liver and heart) and lymphoid organs (Spleen, bursa of Fabricius and all thymic lobes) weight. All weights were expressed as percentages of live body weight.

\section{Blood biochemical Analysis:}

Blood samples were collected from three chicks per treatment, during their exsanguinations, in heparinized tubes, centrifuged at $4000 \mathrm{rpm}$ for $15 \mathrm{~min}$, plasma samples were decanted and then stored at $20^{\circ} \mathrm{C}$ until analysis. Plasma samples were assigned for the determination of total protein, albumin, total lipids, triglycerides, cholesterol and HDL-cholesterol using available commercial kits, while, LDLcholesterol was calculated by the following equation:

LDL Cholesterol $(\mathrm{mg} / \mathrm{dl})=$ Total cholesterol- $($ Triglycerides $/ 5)-$ HDL Cholesterol.

Globulin was calculated by subtraction of plasma albumin from total protein.

\section{Microbiological examination :}

Samples from intestinal contents were randomly collected, and transferred to the laboratory without delay to be examined.

\section{Cultivation media:}

1- (NA) Nutrient Agar (Merck 1994, Cat. No.10233)

2- MacConkey agar (Merck 1994, Cat. No. 5465)

\section{Preparation of examined broiler samples:}

Samples were collected at slaughter, after scalding and de-feathering, but before washing and cooling of carcasses, then placed individually in plastic jars without transport medium. One gram of the tested broiler sample from the intestinal content was placed in a sterile plastic bag. An appropriate amount of sterile phosphate buffer of $\mathrm{pH} 7.0$ was added, massaged for 2 minutes. Before the examination, the sample was then removed into a sterile empty Petri dish to be cut to small pieces using an alcohol sterilized cutter under aseptic conditions.

\section{Microbial cultivation media:}

Digestive tract E. coli colonies counts were determined as colony forming units (cfu) per gram of sample. 


\section{Statistical analysis:}

Data were subjected to the analysis of variance by using the General Linear Models Procedure of the Statistical Analysis System (SAS, 2003). Differences among treatment means were detected using Duncan's multiple range test (Duncan, 1955).

\section{RESULTS AND DISCUSSION}

The effects of in ovo injection and adding vitamin $\mathrm{C}$ into the drinking water on the production parameters of broiler chicks during the whole experimental period ( 1-35 days of age ) are shown in Table (1).

It is clearly noted from the present results that both of in ovo injection with FA treatments during incubation and VC $(40 \mathrm{mg} / \mathrm{L})$ into the drinking water of post hatched chicks significantly improved body weight, carcass parts yield and giblets of broiler chicks as compared to other groups. This may be due to the anabolic effect of FA treatment on muscle building. This study affirmed the findings of Robel (1993), who used folic acid treatments in turkey, and Gursu et al. (2004) who studied effects of vitamin C and folic acid supplementation on serum paraoxonase activity and metabolites induced by heat stress. The improvement in body weight due to vitamins administration in the present study was in agreement with several previous investigations which used same vitamins in poultry feed (El Barkouky et al., 2010; Khan et al., 2010). Vitamin C (ascorbic acid) is a well-known low molecular weight antioxidant that protects the cellular compartment from water-soluble oxygen and nitrogen radicals (Jurczuk et al., 2007).

Table (1). Effect of in ovo injection by folic acid and post hatch addition of Vitamin C on carcass yield and giblets weight of broiler chicks.

\begin{tabular}{|c|c|c|c|c|c|c|c|}
\hline Treatment & $\begin{array}{l}\text { Live body } \\
\text { weight }(g)\end{array}$ & $\begin{array}{c}\text { Carcass } \\
\text { weight } \\
(\%)\end{array}$ & $\begin{array}{c}\text { Breast } \\
\text { weight } \\
(\%)\end{array}$ & $\begin{array}{c}\text { Thigh } \\
\text { weight } \\
(\%)\end{array}$ & $\begin{array}{c}\text { Liver } \\
\text { weight } \\
(\%)\end{array}$ & $\begin{array}{c}\text { Heart } \\
\text { weight } \\
(\%) \\
\end{array}$ & $\begin{array}{c}\text { Fat weight } \\
(\%)\end{array}$ \\
\hline \multicolumn{8}{|c|}{ Injection -effect (T) } \\
\hline $\mathrm{T} 1$ & $2150.0 \pm 168.9^{b}$ & $72.9 \pm 1.8^{\mathrm{b}}$ & $25.7 \pm 1.5^{\mathrm{b}}$ & $23.3 \pm 0.9$ & $2.6 \pm 0.2^{\mathrm{b}}$ & $0.64 \pm 0.08$ & $2.80 \pm 0.61^{\mathrm{a}}$ \\
\hline $\mathrm{T} 2$ & $2271.7 \pm 174.9^{b}$ & $72.4 \pm 3.1^{\mathrm{b}}$ & $26.9 \pm 1.2^{\mathrm{ab}}$ & $23.3 \pm 1.1$ & $2.7 \pm 0.2^{\mathrm{ab}}$ & $0.63 \pm 0.05$ & $2.14 \pm 0.20^{\mathrm{ab}}$ \\
\hline $\mathrm{T} 3$ & $2837.8 \pm 62.2^{\mathrm{a}}$ & $81.8 \pm 0.5^{\mathrm{a}}$ & $31.5 \pm 0.6^{\mathrm{a}}$ & $26.1 \pm 0.6$ & $3.2 \pm 0.1^{\mathrm{a}}$ & $0.67 \pm 0.03$ & $1.44 \pm 0.14^{\mathrm{b}}$ \\
\hline Sig. & $* *$ & $* * *$ & $*$ & NS & $*$ & NS & $*$ \\
\hline \multicolumn{8}{|c|}{ Vitamin C - effect } \\
\hline $\mathrm{C} 1$ & $2132.8 \pm 154.5^{b}$ & $72.1 \pm 2.7^{\mathrm{b}}$ & $26.0 \pm 1.4^{\mathrm{b}}$ & $23.09 \pm 0.7^{b}$ & $2.56 \pm 0.17^{\mathrm{b}}$ & $0.57 \pm 0.04^{b}$ & $2.50 \pm 0.35^{\mathrm{a}}$ \\
\hline $\mathrm{C} 2$ & $2706.9 \pm 65.3^{\mathrm{a}}$ & $79.3 \pm 0.8^{\mathrm{a}}$ & $30.04 \pm 0.7^{\mathrm{a}}$ & $25.4 \pm 0.56^{\mathrm{a}}$ & $3.09 \pm 0.04^{\mathrm{a}}$ & $0.72 \pm 0.04^{\mathrm{a}}$ & $1.70 \pm 0.12^{\mathrm{b}}$ \\
\hline Sig. & $* * *$ & $* * *$ & $* * *$ & $*$ & $* * *$ & $* *$ & $* *$ \\
\hline \multicolumn{8}{|c|}{ Interaction $\mathrm{T} \times \mathrm{C}$} \\
\hline $\mathrm{T} 1 * \mathrm{C} 1$ & $1776.7 \pm 20.3$ & $69.1 \pm 0.5$ & $22.7 \pm 1.1$ & $21.8 \pm 0.1$ & $2.2 \pm 0.2$ & $0.47 \pm 0.02$ & $3.54 \pm 0.45$ \\
\hline $\mathrm{T} 1 * \mathrm{C} 2$ & $2523.3 \pm 53.7$ & $76.6 \pm 0.9$ & $28.7 \pm 1.3$ & $24.8 \pm 1.3$ & $3.0 \pm 0.1$ & $0.80 \pm 0.07$ & $2.00 \pm 0.14$ \\
\hline $\mathrm{T} 2 * \mathrm{C} 1$ & $1881.7 \pm 31.1$ & $65.6 \pm 0.6$ & $24.1 \pm 0.3$ & $21.9 \pm 0.4$ & $2.3 \pm 0.1$ & $0.53 \pm 0.04$ & $2.59 \pm 0.06$ \\
\hline $\mathrm{T} 2 * \mathrm{C} 2$ & $2661.7 \pm 6.1$ & $79.3 \pm 0.4$ & $29.6 \pm 0.2$ & $24.7 \pm 0.7$ & $3.2 \pm 0.1$ & $0.61 \pm 0.03$ & $1.70 \pm 0.05$ \\
\hline $\mathrm{T} 3 * \mathrm{C} 1$ & $2740.0 \pm 75.1$ & $81.7 \pm 1.7$ & $31.1 \pm 0.5$ & $25.5 \pm 1.1$ & $3.2 \pm 0.1$ & $0.71 \pm 0.04$ & $1.38 \pm 0.29$ \\
\hline $\mathrm{T} 3 * \mathrm{C} 2$ & $2935.7 \pm 64.3$ & $82.0 \pm 0.4$ & $31.9 \pm 1.2$ & $26.7 \pm 0.4$ & $3.1 \pm 0.1$ & $0.74 \pm 0.04$ & $1.49 \pm 0.11$ \\
\hline Sig. & $* * *$ & $* * *$ & $* *$ & NS & $* * *$ & $* *$ & $* *$ \\
\hline
\end{tabular}

T1: (control); T2:in ovo injection with distilled water/egg; T3: in ovo injection with folic acid; C1 and C2 : vitamin

(C) into the drinking water as follow ( 0 and $40 \mathrm{mg} / \mathrm{l}$ water, respectively).

$* P 0.05$, **P 0.01, *** P 0.001, NS = non-significant.

$A$ and $b$ Means within columns with no common superscripts differ significantly

Vitamin $\mathrm{C}$ efficiently inhibits in vitro lipid peroxidation due to a combination of direct radical interception and interaction with $\alpha$-tocopherol as a co-antioxidant (Verma et al., 2007). Kultu, (2001) reported that VC supplementation increased body weight gain, carcass weight and concluded that ascorbic acid supplementation improved the productive performance of broiler chicks with experimentally induced hypothyroidism. In addition, $\mathrm{VC}$ is required for the hydroxylation of essential amino acids and of several oxidase enzymes (Dawson et al., 1990). Vitamin C could still play a role in 
these findings as it has been shown that it takes part in the synthesis of leukocytes especially phagocytes and neutrophiles which play a part in the defense system of the chickens. In respect to VC, McKee and Harrison (1995) found that vitamin C increased the growth rate and improved the tolerability to stress and reduced the mortality. Also, Mona et al. (2004) reported that VC improved average body weight and this effect may be related to collagen synthesis, calcium and vitamin D3 metabolism as well as carnitine synthesis required for oxidation of fatty acid to obtain energy.

The results shown in Table (1) indicated that in ovo injection with FA during incubation and VC addition into drinking water caused a significant increase in the breast and thigh muscles weight of chicks at 5 weeks of age. This effect may be due to that the positive effects of FA and VC on breast muscles yield reflect their beneficial use in improving muscles yield of broilers. The tibia bone is the fastest growing bone in the body and is considered as the most sensitive during embryogenesis. Pirsljin et al. (2008) reported that one of the methods to assure an adequate nutrient content in the egg is in ovo administration of nutrients, which increases hatching weight and the size of the breast muscle. The improved performance could possibly be effected by vitamin $\mathrm{C}$ in neutralizing the negative impact of heat stress. VC is capable of minimizing oxidation within the tissues (Phoprasit et al., 2014).

The results in Table (1) indicated that in ovo injection by FA and VC administration in water drinking was significantly reduced the total body fat followed by folic acid compared with the control groups.

The birds whose drinking water was supplemented with $\mathrm{vC}$ showed increased body weight and carcass parts weight. However, these treatments did demonstrate high influence on percent of abdominal fats. These results are in agreement with those reported by (Phoprasit et al., 2014). Kultu (2001) stated that Vit. C supplementation reduced carcass fat content.

Table. (2) shows the effect of in ovo injection with FA and VC supplementation in water on the relative weights of lymphoid organs. There were significant increases in lymphoid organs weight (\%) in chicks that hatched from FA- in ovo injected eggs compared with the other groups. Also, VC addition significantly improved lymphoid organs weight, regardless in ovo FA injection. Moreover, the interaction between both in ovo FA injection and VC was significant in this respect.

Table (2). Effect of in ovo injection by folic acid during and post hatch addition of Vitamin $\mathrm{C}$ on lymphoid organs weight and some plasma constituents.

\begin{tabular}{|c|c|c|c|c|c|c|c|}
\hline Treat. & Bursa $\%$ & Thymus\% & Spleen $\%$ & $\begin{array}{c}\text { Total } \\
\text { protein } \\
(\mathrm{g} / \mathrm{dl})\end{array}$ & $\begin{array}{l}\text { Albumin } \\
(\mathrm{g} / \mathrm{dl})\end{array}$ & $\begin{array}{l}\text { Globulin } \\
(\mathrm{g} / \mathrm{dl})\end{array}$ & Glucose $(\mathrm{g} / \mathrm{dl})$ \\
\hline \multicolumn{8}{|c|}{ Injection Treatment $(\mathrm{T})$} \\
\hline $\mathrm{T} 1$ & $0.20 \pm 0.01^{\mathrm{b}}$ & $0.61 \pm 0.01^{\mathrm{b}}$ & $0.14 \pm 0.02^{b}$ & $6.16 \pm 0.26^{\mathrm{b}}$ & $3.35 \pm 0.10^{\mathrm{b}}$ & $2.81 \pm 0.23^{\mathrm{b}}$ & $197.17 \pm 12.78$ \\
\hline $\mathrm{T} 2$ & $0.24 \pm 0.02^{\mathrm{b}}$ & $0.63 \pm 0.07^{\mathrm{b}}$ & $0.15 \pm 0.02^{b}$ & $6.08 \pm 0.34^{\mathrm{b}}$ & $3.30 \pm 0.14^{\mathrm{b}}$ & $2.78 \pm 0.21^{b}$ & $206.83 \pm 7.83$ \\
\hline $\mathrm{T} 3$ & $0.33 \pm 0.01^{\mathrm{a}}$ & $0.78 \pm 0.02^{\mathrm{a}}$ & $0.19 \pm 0.01^{\mathrm{a}}$ & $7.23 \pm 0.23^{\mathrm{a}}$ & $3.96 \pm 0.15^{\mathrm{a}}$ & $3.27 \pm 0.13^{\mathrm{a}}$ & $178.83 \pm 5.38$ \\
\hline Sig. & $* *$ & $*$ & $*$ & $* *$ & $*$ & $*$ & NS \\
\hline \multicolumn{8}{|c|}{ Vitamin $\mathrm{C}-$ effect } \\
\hline $\mathrm{C} 1$ & $0.24 \pm 0.03^{\mathrm{b}}$ & $0.57 \pm 0.05^{\mathrm{b}}$ & $0.13 \pm 0.02^{\mathrm{b}}$ & $6.40 \pm 0.36$ & $3.49 \pm 0.19$ & $2.91 \pm 0.21$ & $210.11 \pm 6.72^{\mathrm{a}}$ \\
\hline $\mathrm{C} 2$ & $0.28 \pm 0.01^{\mathrm{a}}$ & $0.78 \pm 0.02^{\mathrm{a}}$ & $0.19 \pm 0.01^{\mathrm{a}}$ & $6.58 \pm 0.33$ & $3.59 \pm 0.16$ & $3.00 \pm 0.18$ & $178.44 \pm 5.62^{b}$ \\
\hline Sig. & $* *$ & $*$ & $* *$ & NS & NS & NS & $* *$ \\
\hline \multicolumn{8}{|c|}{ Interaction T X C } \\
\hline $\mathrm{T} 1 * \mathrm{C} 1$ & $0.19 \pm 0.01$ & $0.43 \pm 0.09$ & $0.10 \pm 0.01$ & $5.79 \pm 0.43$ & $3.16 \pm 0.12$ & $2.63 \pm 0.45$ & $222.00 \pm 2.89$ \\
\hline $\mathrm{T} 1 * \mathrm{C} 2$ & $0.22 \pm 0.01$ & $0.80 \pm 0.05$ & $0.18 \pm 0.01$ & $6.52 \pm 0.13$ & $3.53 \pm 0.05$ & $2.99 \pm 0.15$ & $172.33 \pm 13.86$ \\
\hline $\begin{array}{l}\mathrm{T} 2 * \\
\mathrm{C} 1\end{array}$ & $0.19 \pm 0.01$ & $0.50 \pm 0.01$ & $0.10 \pm 0.02$ & $5.93 \pm 0.53$ & $3.28 \pm 0.19$ & $2.65 \pm 0.33$ & $222.33 \pm 4.84$ \\
\hline $\begin{array}{l}\mathrm{T} 2 * \\
\mathrm{C} 2\end{array}$ & $0.29 \pm 0.01$ & $0.75 \pm 0.03$ & $0.20 \pm 0.01$ & $6.23 \pm 0.52$ & $3.32 \pm 0.24$ & $2.91 \pm 0.31$ & $191.33 \pm 6.57$ \\
\hline $\mathrm{T} 3 * \mathrm{C} 1$ & $0.33 \pm 0.01$ & $0.76 \pm 0.04$ & $0.20 \pm 0.01$ & $7.17 \pm 0.78$ & $3.98 \pm 0.42$ & $3.19 \pm 0.37$ & $186.00 \pm 8.62$ \\
\hline $\begin{array}{l}\text { T3* } \\
\text { C2 }\end{array}$ & $0.33 \pm 0.01$ & $0.80 \pm 0.04$ & $0.20 \pm 0.03$ & $7.29 \pm 0.74$ & $3.94 \pm 0.38$ & $3.35 \pm 0.35$ & $171.67 \pm 4.33$ \\
\hline Sig. & $*$ & * & $*$ & NS & $\mathrm{NS}$ & NS & NS \\
\hline
\end{tabular}

T1: (control); T2:in ovo injection with distilled water/egg; T3: in ovo injection with folic acid; C1 and C2

: vitamin $(C)$ into the drinking water as follow (0 and $40 \mathrm{mg} / \mathrm{l}$ water, respectively).

*P 0.05, **P 0.01, ***P 0.001, NS= non-significant.

$A$ and $b$ Means within columns with no common superscripts differ significantly 
This improvement could possibly be ascribed to the anabolic effect of various treatments of injection folic acid and vitamin $\mathrm{C}$ on muscle building where heart consists mainly of muscles. VC plays a part in the defense system of the chickens. The antioxidant function of these vitamins could, at least in part, enhance immunity by maintaining the functional and structural integrity of important immune cells and hence decrease animal morbidity and mortality (Chew, 1995). The protective effects of VC on health may partially be a result of reducing circulating levels of glucocorticoids (Nockels, 1990). Since during stress, glucocorticoids, which suppress the immune response, are elevated.

\section{Blood Constituents:}

Results in Table (2) showed that in ovo injection with folic acid significantly increased plasma total proteins, albumin and globulin of chicks at 5 weeks compared with chicks of other groups. However, VC had no effect. This may reflect the effect of folic acid on protein metabolism during embryogenesis. Moreover, folic acid results are in close agreement with the findings by Hebert et al. (2005) who worked on folic acid. The interaction effect of FA and VC on plasma protein fraction was not significant.

Vitamin C may increase oxygen metabolism of tissues and activity in broiler, due to increased nutrients utilization and use of blood glucose, as observed in Table-2 where VC administration significantly decreased blood glucose, indicative of higher metabolic rate.

The results concerning the effects of in ovo injection of folic acid on plasma total lipids and triglycerides are presented in Table (3).

Results showed that folic acid and vitamin $\mathrm{C}$ treatments significantly decreased plasma level of total lipids, cholesterol and triglycerides.

Table (3). Effect of in ovo injection by folic acid during embryogenesis and adding Vitamin $\mathrm{C}$ into the drinking water on some plasma constituents( $\mathrm{mg} / \mathrm{dl})$ :

\begin{tabular}{|c|c|c|c|c|c|c|}
\hline Treatment & Cholesterol & Total lipids & Triglycerides & HDL & LDL & $\mathrm{L} / \mathrm{H}$ ratio \\
\hline \multicolumn{7}{|c|}{ Injection Treatment $(\mathrm{T})$} \\
\hline $\mathrm{T} 1$ & $170.4 \pm 12.7^{\mathrm{a}}$ & $698.4 \pm 23.7^{\mathrm{a}}$ & $80.2 \pm 3.5^{\mathrm{a}}$ & $58.6 \pm 0.2^{b}$ & $95.7 \pm 12.3^{\mathrm{a}}$ & $1.6 \pm 0.2$ \\
\hline $\mathrm{T} 2$ & $145.7 \pm 3.7^{b}$ & $682.9 \pm 39.6^{\mathrm{a}}$ & $80.1 \pm 3.8^{\mathrm{a}}$ & $58.9 \pm 0.9^{b}$ & $70.8 \pm 4.0^{b}$ & $1.21 \pm 0.1$ \\
\hline $\mathrm{T} 3$ & $141.3 \pm 7.7^{b}$ & $623.3 \pm 10.6^{b}$ & $69.2 \pm 1.6^{\mathrm{b}}$ & $61.3 \pm 0.3^{\mathrm{a}}$ & $66.2 \pm 7.5^{b}$ & $1.08 \pm 0.1$ \\
\hline Sig. & $*$ & $*$ & $*$ & $* *$ & $*$ & NS \\
\hline \multicolumn{7}{|c|}{ Vitamin C-effect } \\
\hline $\mathrm{C} 1$ & $164.3 \pm 9.7^{\mathrm{a}}$ & $717.4 \pm 22.1^{\mathrm{a}}$ & $81.8 \pm 3.0^{\mathrm{a}}$ & $58.9 \pm 0.6^{\mathrm{b}}$ & $89.0 \pm 9.6^{\mathrm{a}}$ & $1.5 \pm 0.1^{\mathrm{a}}$ \\
\hline $\mathrm{C} 2$ & $140.6 \pm 3.1^{b}$ & $619.1 \pm 10.2^{b}$ & $71.2 \pm 1.7^{\mathrm{b}}$ & $60.2 \pm 0.4^{\mathrm{a}}$ & $66.2 \pm 3.1^{\mathrm{b}}$ & $1.1 \pm 0.05^{b}$ \\
\hline Sig. & $* * *$ & $* * *$ & $* *$ & $* * *$ & $* * *$ & $* * *$ \\
\hline \multicolumn{7}{|c|}{ Interaction $\mathrm{T}$ X C } \\
\hline $\mathrm{T} 1 * \mathrm{C} 1$ & $87.22 \pm 1.89$ & $198.55 \pm 2.55$ & $749.76 \pm 11.38$ & $58.30 \pm 0.12$ & $122.81 \pm 3.01$ & $2.11 \pm 0.06$ \\
\hline $\mathrm{T} 1 * \mathrm{C} 2$ & $73.18 \pm 2.69$ & $142.15 \pm 2.92$ & $646.95 \pm 5.07$ & $58.90 \pm 0.12$ & $68.62 \pm 3.47$ & $1.17 \pm 0.06$ \\
\hline $\mathrm{T} 2 * \mathrm{C} 1$ & $87.75 \pm 1.88$ & $151.88 \pm 5.07$ & $763.34 \pm 28.54$ & $57.40 \pm 0.55$ & $76.93 \pm 5.99$ & $1.35 \pm 0.12$ \\
\hline $\mathrm{T} 2 * \mathrm{C} 2$ & $72.47 \pm 3.09$ & $139.57 \pm 2.13$ & $602.38 \pm 23.10$ & $60.41 \pm 0.50$ & $64.67 \pm 2.68$ & $1.07 \pm 0.05$ \\
\hline $\mathrm{T} 3 * \mathrm{C} 1$ & $70.37 \pm 1.30$ & $142.53 \pm 13.80$ & $638.96 \pm 15.08$ & $61.18 \pm 0.06$ & $67.27 \pm 3.80$ & $1.10 \pm 0.09$ \\
\hline $\mathrm{T} 3 * \mathrm{C} 2$ & $68.04 \pm 3.02$ & $140.11 \pm 9.93$ & $607.68 \pm 9.51$ & $61.32 \pm 0.62$ & $65.18 \pm 5.64$ & $1.06 \pm 0.15$ \\
\hline Sig. & $* *$ & $*$ & NS & $* *$ & $* *$ & $* *$ \\
\hline
\end{tabular}


The pronounced reduction in plasma total lipids, cholesterol and triglycerides may be associated with increasing triglycerides metabolism as a source of energy in absence of other metabolites required for energy (VFA and glucose levels). Folic acid results are in close agreement with the recent findings by Abd El-Azeem, et al. (2014) who used in ovo injection of folic acid. It is of interest to note that the present differences in both triglycerides and total lipids concentrations may be attributed to change in the concentration of total cholesterol, where the change in total lipids concentration was mainly attributed to change in triglycerides and cholesterol concentration.

In ovo injection with FA during embryogenesis or supplementing drinking water with VC affected the level of HDL while folic acid insignificantly decreased cholesterol at 5 weeks comparable to the other groups. The beneficial effect of drinking water with $\mathrm{VC}$ administration reducing the plasma concentration of triglycerides, cholesterol and LDL. Folic acid and VC reduced the concentration of cholesterol, triglycerides, free fatty acids, phospholipids and very low density lipoproteins (VLDL). Therefore, it may be concluded that vitamin $\mathrm{C}$ may be used with water to get best result in terms of body weight gain, physical appearance and blood profiles without any detrimental effects on broilers.

\section{Microbiological examination :}

Total microbial counting of intestinal contents :

The total microbial count (cfu x $10^{3} / \mathrm{g}$ sample) of intestine contents of the tested broilers was measured and the obtained results are listed in Table (4).

Table (4). Effect of in ovo injection by folic acid and adding Vitamin $\mathrm{C}$ into the drinking water on total bacterial count of intestinal contents $\left(\mathrm{cfu} \times 10^{3} / \mathrm{g}\right)$.

\begin{tabular}{|c|c|c|}
\hline Treatment & Total Count of bacteria & Count of E. Coli \\
\hline \multicolumn{3}{|c|}{ Injection Treatment $(\mathrm{T})$} \\
\hline $\mathrm{T} 1$ & $849 \pm 47.9^{b}$ & $110.3 \pm 21.8^{\mathrm{a}}$ \\
\hline $\mathrm{T} 2$ & $837.0 \pm 46.4^{\mathrm{b}}$ & $111.6 \pm 27.7^{\mathrm{a}}$ \\
\hline T3 & $1161.2 \pm 52.4^{\mathrm{a}}$ & $64.3 \pm 18.2^{\mathrm{b}}$ \\
\hline Sig. & $* * *$ & $* *$ \\
\hline \multicolumn{3}{|c|}{ Vitamin $\mathrm{C}$ into the drinking water treatment } \\
\hline $\mathrm{C} 1$ & $847.9 \pm 56.5^{\mathrm{b}}$ & $136.6 \pm 12.2^{\mathrm{a}}$ \\
\hline $\mathrm{C} 2$ & $1050.2 \pm 53.6^{\mathrm{a}}$ & $54.2 \pm 12.8^{\mathrm{b}}$ \\
\hline Sig. & $* * *$ & $* *$ \\
\hline \multicolumn{3}{|c|}{ Interaction $\mathrm{T} \times \mathrm{C}$} \\
\hline $\mathrm{T} 1 * \mathrm{C} 1$ & $745.0 \pm 14.4$ & $140.7 \pm 11.1$ \\
\hline $\mathrm{T} 1 * \mathrm{C} 2$ & $953.0 \pm 20.8$ & $80.0 \pm 36.5$ \\
\hline $\mathrm{T} 2 * \mathrm{C} 1$ & $736.0 \pm 10.4$ & $171.5 \pm 15.6$ \\
\hline $\mathrm{T} 2 * \mathrm{C} 2$ & $938.0 \pm 20.8$ & $51.7 \pm 3.8$ \\
\hline $\mathrm{T} 3 * \mathrm{C} 1$ & $1062.7 \pm 58.3$ & $97.7 \pm 5.5$ \\
\hline $\mathrm{T} 3 * \mathrm{C} 2$ & $1259.7 \pm 24.6$ & $31.0 \pm 2.7$ \\
\hline Sig. & $*$ & $*$ \\
\hline
\end{tabular}

The results showed that the addition of vitamin $\mathrm{C}$ significantly decreased the count of Escherichia coli compared to the control treatments, which had more effective than the control group on decreasing intestinal count of Escherichia coli. However, VC and folic acid treatments increased the total viable bacterial count. It appears that VC with its acidic properties can affect the bacterial counts in the digestive tract of chicks. In this concern, Lampromsuk et al. (2012) reported that organic acids increase the population of lactic acid bacteria in the intestinal tract which produce lactic and acetic acids. This in turn could be used by chicks as an energy source for intestinal epithelial cell growth that improves nutrient absorption. In the present study, both folic acid and vitamin $\mathrm{C}$ significantly increased the total viable bacterial count which in close agreement with the previous results . 


\section{CONCLUSIONS}

It is concluded that in ovo injection of FA at the $7^{\text {th }}$ day of embryogenesis followed by Vit. C supplementation to drinking water of hatched chicks, could be applied to improve live body weight, carcass characteristics, lymphoid organs weight, reduce plasma lipids and pathogenic bacterial count in the cecal contents.

\section{REFERENCES}

Abd El-Azeem, Nafisa, A.; Marwa, Sh. Abdo; M. Madkour and I. El-Wardany (2014). Physiological and histological responses of broiler chicks to in ovo injection with folic acid or L-Carnitine during embryogenesis. Global Vet., 13 (4): 544-551.

Amakye-Anim, J; T. Lin; P. Y. Hester, D. Thiagarajan; B.A. Watkins and C. C. Wu (2000). Ascorbic acid supplementation improved antibody response to infectious bursal disease vaccination in chickens. Poultry Sci ,79(5):680-8.

Bain, B. S. (1996). The role of Vitamin C in stress management. World Poultry, 12(4): 38-41.

Chew, B. P. (1995). Antioxidant vitamins affect food animal immunity and health. J. Nutr. Jun;125(6 Suppl.):1804S-1808S.

Dawson, E.B.; W. A. Harris; L. C. Powell (1990). Relationship between ascorbic acid and male fertility. World Rev. Nutr. Diet. 62, 1-26.

Duncan, D.B. (1955). Multiple range test and multiple F Tests. Biometrics, 11: 1-42.

El Barkouky, E. M.; F. R. Mohamed; A. M. Atta; A. M. Abu Taleb; M. A. El-Menawey and M. H. Hatab (2010). Effect of Saccharomyces Cerevisiae and Vitamin C Supplementation on Performance of Broilers Subjected to Ochratoxin A Contamination. Egypt. Poult. Sci., 30 (I): 89-113.

Foye, O. T.; P. R. Ferket and Z. Uni (2007). The effects of in ovo feeding arginine, hydroxyl, methylbutyrate, and protein on jejunal digestive and absorptive activity in embryonic and neonatal turkey poults. Poult. Sci., 86: 2343-2349.

Gursu, M.F.; M. Onderci; F. Gulcu and K. Sahin (2004). Effects of vitamin C and folic acid supplementation on serum paraoxonase activity and metabolites induced by heat stress in vivo. Nutr. Res., 24: 157-164.

Hajihosaini, M. and M. Mottaghitalab (2004). Effect of amino acid injection in broiler breeder eggs on hatchability and growth of hatched chicken. J. Agric. Sci., 1: 23-32.

Hargis, P. S.; S. L. Pardue; A. M. Lee and G. W. Sandel (1989). In ovo growth hormone alters growth and adipose tissue development of chickens. Growth Devel. Aging. 53: 93-99.

Havenstein, B.; P. R. Ferket and M. A. Qureshi (2003). Carcass composition and yield of 1957 versus 2001 broilers when fed representative 1957 and 2001 broiler diets. Poult. Sci., 82: 1509-1518.

Hebert, K.; J. D. House and W. Guenter (2005). Effect of dietary folic acid supplementation on egg folate content and the performance and folate status of two strains of laying hens. Poult. Sci., 84. 1533-1538.

Jochemsen, P. and S. H. M. Jeurissen (2002). The localization and uptake of in ovo injected soluble and particulate substances in the chicken. Poult. Sci., 81: 1811-1817.

Jurczuk, M.; M. M. Brzóska and J. Moniuszko-Jakoniuk (2007). Hepatic and renal concentrations of vitamins $\mathrm{E}$ and $\mathrm{C}$ in lead- and ethanol-exposed rats. An assessmen of their involvement in the mechanisms of peroxidative damage. Food Chem. Toxicol, 45, 1478-1486.

Khan, W. A. M.; Z. Khan; A. Khan and I. Hussain. (2010). Pathological Effects of Aflatoxin and Their Amelioration by Vitamin E in White Leghorn Layers. Pak Vet J, 30(3): 155-162. 
Kultu, H. R. (2001). Influences of wet feeding and supplementing with ascorbic acid on performance and carcass composition of broiler chicks exposed to high ambient temperature.Arch. Tierernahr 54 (2):127-139.

Lampromsuk, P.; C. Bunchasak; C. Kaewtapee; S. Sawanon and T. Poeikhampha (2012). Effect of supplementing acidifiers and organic zinc in diet on growth performances and gut conditions of pigs. J. Applied Sci., 12: 553-560.

McKee, J. S.; and P. C. Harrison (1995). Effects of supplemental ascorbic acid on the performance of broiler chickens exposed to multiple concurrent stresses. Poult. Sci , 74: 1772-1785.

Merck (1994). Microbiology manual E. Merck Darmstaadt, Bereich labor, D-64271, Darmstaadt Germany.

Mona, M. A.; F.M. El-Kady; and A. S. Abdel-Moneim (2004). Trial for improving protection against infection bursal disease virus in vaccinated chicks by natural immunodulators. Proceeding 6th Scientific conference of the Egyptian veterinary poultry association under the auspices of the minister of agriculture and land reclamation. September 25-27th , 2004, The Egyptian International Agriculture Center. pp 214-223.

Nockels, C. F. (1990). Starch digestion and digesta kinetics in the small intestine of steersfed on a maize grain and maize silage mixture. Animal feed science and technology,30, 79-89.

Ohta, Y.; N. Tsushima; K. Koide; M. T. Kidd and T. Ishibashi (1999). Effect of amino acid injection in broiler breeder egg on embryonic growth and hatchability of chicks. Poult. Sci., 78: 1493-1498.

Pirsljin, J.; S. Milinkovic-Tur; B. Beer Ljubic and M. Zdelar-Tuk (2008). The effect of organic selenium supplementation on antioxidative characteristics and lipid peroxidation in chicken blood during fattening and after fasting. Vet. Arhiv., 78: 187-196.

Phoprasit, P.; C. Bunchasak; C. Rakangthong and T. Poeikhampha (2014). Effects of Adding Vitamins and Organic Acids into the Drinking Water on Growth Performance, Carcass Yield and Meat Quality of Broilers Raised Under Tropical Condition. J. of applied science 14(24):3493:3499.

Robel, E. J. (1993). Evaluation of egg injection of folic acid and effect of supplemental folic acid on hatchability and poult weight. Poult. Sci., 72: 546-553.

SAS, (2003). SAS proprietary Software, Release 9. 1. Cary, NC. SAS Institute, Inc.

Selim, Sh. A.; K. M. Gaafar and S. S. El-ballal (2012). Influence of in ovoadministration with vitamin E and ascorbic acid on the performance of Muscovy ducks. Emir. J. Food Agric., 24 (3): 264-271.

Skinner, J. T., A. L. Izat and P.W. Waldroup (1991). Research note: Fumaric acid enhances performance of broiler chickens. Poult. Sci., 70: 1444-1447.

Takahashi, K.; Y. Akiba and M. Horiguchi (1991). Effects of supplemental ascorbic acid on performance, organ weight and plasma cholesterol concentration in broiler treated with propylthiouracil, in British Poultry Science 32 (3): 545-554

Tako, E.; P. R. Ferket and Z. Uni (2004). Effects of in ovo feeding ofcarbohydrates and $\beta$-hydroxy- $\beta$ methylbutyrate on the developmentof chicken intestine. Poult. Sci., 83: 2023-2028.

Tako, E.; P. R. Ferket, and Z. Uni (2005). Changes in chicken intestinal zinc exporter mRNA expression and small intestinal functionality following intra-amniotic zinc methionine administration. J. Nutr. Biochem., 16: 339-346.

Verma, R.S.; A. Mehta and N. Srivastava (2007). In vivo chlorpyrifos induced oxidative stress: attenuation by antioxidant vitamins. Pestic. Biochem. Phys., (88):191-196. 
تأثير حقن بيض التفريخ بحمض الفوليك ثم إضافة فيتامين (ج) لمياه الثرب بعد الفقس على الأداء الإتتاجى والمناعى وبعض مكونات الام لكتاكيت اللحم

إيمان أحمد السعيد

قسم إنتاج الدواجن- كلية النزراعة - جامعة دمباطـ مصر

أجريت هذه الدراسة التقييم تأثير حقن بيض التفريخ بحمض الفوليك واضافة فيتامين (ج) ليلياه الثرب بعد الفتس على الأداء الإنتاجى

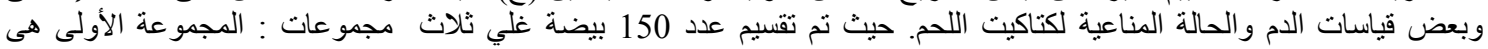

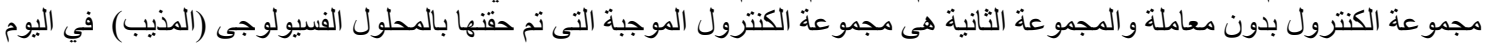

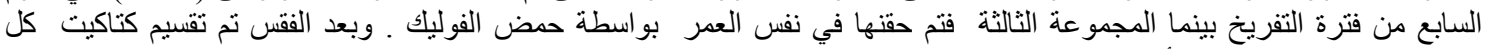

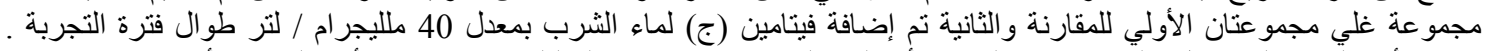

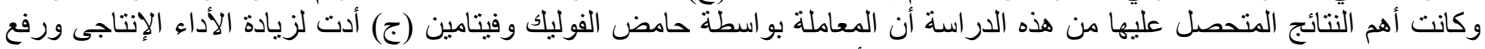

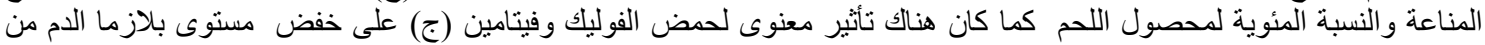

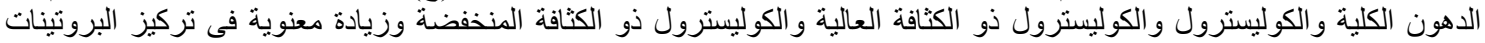

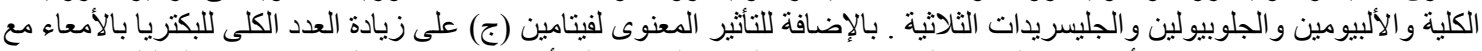

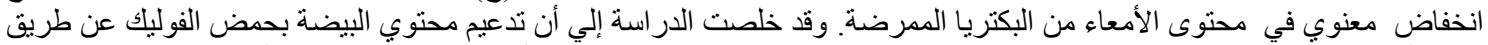

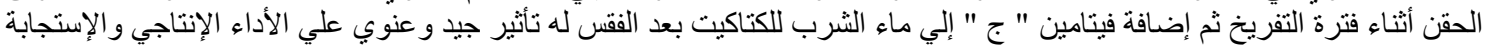
المناعية لكتاكيت اللدم. 